\title{
IDENTIFIKASI PENGETAHUAN DAN PENGGUNAAN PRODUK ANTIKETOMBE PADA MAHASISWA UPN VETERAN SURABAYA
}

\author{
Putri Dwi Widowati, Qatrunnada Rafifa Zalfani, Adinda Vidya Lestari, Septivani Nur Syahbana, Nadhifa Razani Aksan \\ Putri, Rival Yoga Sena, Dina Afifah Binti Wulandari, Agni Kartika Prabansari, Natasha Gebyta Fajrin, Anila Impian
} Sukorini

Departemen Farmasi Komunitas, Fakultas Farmasi, Universitas Airlangga Gedung Nanizar Zaman Joenoes Kampus C, Jl. Ir. Soekarno, Surabaya 60115, Indonesia

E-mail: anila-i-s@ff.unair.ac.id

\begin{abstract}
ABSTRAK
Ketombe merupakan salah satu permasalahan kulit yang sering terjadi di masyarakat. Prevalensi penderita ketombe di dunia mencapai 50\% dari keseluruhan populasi. Meskipun demikian, kesadaran masyarakat akan masalah ketombe masih kurang. Sedangkan apabila ketombe tidak diatasi, dapat menimbulkan permasalahan kulit lain, masalah psikologis, dan menimbulkan kesan tidak higienis. Prevalensi ketombe pada laki-laki lebih besar daripada perempuan. Oleh karena itu, penelitian ini dilakukan untuk mengidentifikasi pengetahuan dan penggunaan produk antiketombe pada 98 mahasiswa lakilaki UPN Veteran Surabaya. Metode penelitian yang digunakan adalah penelitian cross-sectional dan berupa penelitian deskriptif. Instrumen yang digunakan berupa self-administerred questionnaire. Berdasarkan hasil survei, responden memiliki pengetahuan yang kurang mengenai adanya efek samping dari produk antiketombe $(39,8 \%$; $n=98)$ dan macammacam penyebab ketombe $(33,7 \% ; n=98)$. Adapun dalam penggunaan produk antiketombe, dua faktor pertimbangan terbanyak yakni faktor merk $(29,1 \% ; n=55)$ dan faktor indikasi yang sesuai $(27,3 \% ; n=55)$. Hasil survey menunjukkan pula kurangnya kewaspadaan mahasiswa terhadap efek samping produk antiketombe $(5,5 \% ; n=55)$.
\end{abstract}

Kata Kunci: ketombe, produk antiketombe, pengetahuan, perilaku penggunaan

\begin{abstract}
Dandruff is one of skin problems in public. The prevalence of dandruff sufferers in the world reaches $50 \%$ of the total population. Nevertheless, public awareness of the dandruff problems is still low. While dandruff can't be solved, it can cause other skin problems, psychological problems, and cause unhygienic impression. The prevalence of dandruff in male respondents is greater than female. Therefore, this research was conducted to identify the knowledge and utilization of antidandruff products to 98 UPN Veteran Surabaya male students. The research method was a cross-sectional study and consisted of descriptive research. The instrument was self-administered questionnaires. Based on this survey, students had less knowledge about the side effects of anti-dandruff products $(39.8 \% ; n=98)$ and about other various causes of dandruff $(33.7 \% ; \mathrm{n}=98)$. Whereas in the use of anti-dandruff products, the two most considered factors were brands $(29.1 \% ; \mathrm{n}=55)$ and indication $(27.3 \% ; \mathrm{n}=55)$. This survey showed that the respondensts had less awareness of the side effects of antidandruff products $(5.5 \% ; \mathrm{n}=55)$.
\end{abstract}

Keywords: dandruff, anti-dandruff products, knowledge, utilization behavior 


\section{PENDAHULUAN}

Ketombe adalah kondisi kulit dimana terjadi pengelupasan sel-sel kulit mati yang berlebihan, pada umumnya berbentuk serpihan berwarna putih atau kekuningan. Ketombe dapat terjadi di alis dan kulit kepala, namun umumnya terjadi di kulit kepala. Ketombe merupakan salah satu permasalahan kulit yang sering terjadi di masyarakat. Beberapa penelitian telah menunjukkan prevalensi penderita ketombe di dunia yakni mencapai $50 \%$ dari keseluruhan populasi (Ranganathan dan Mukhopadhyay, 2010). Ketombe dapat dialami oleh laki-laki maupun perempuan. Namun, berdasarkan penelitian yang dilakukan oleh Misery et al. pada tahun 2013, prevalensi ketombe pada responden laki-laki sebesar 20,7\%, sedangkan pada responden perempuan sebesar $12,8 \%$.

Prevalensi penderita ketombe pada laki-laki dan perempuan berbeda, yang mana laki-laki penderita ketombe cenderung lebih tinggi daripada perempuan penderita ketombe. Hal ini dikarenakan laki-laki memiliki hormon androgen yang lebih tinggi daripada perempuan. Sehingga, tingginya hormon androgen meningkatkan resiko ketombe pada laki-laki (Manuel dan Ranganathan, 2011). Selain tingginya hormon androgen, ketombe dapat disebabkan oleh faktor lain seperti perbedaan demografi (umur, gender, dan ras), riwayat kesehatan (seperti riwayat memiliki eksema dan psoriasis), gaya hidup (higienitas, asupan makanan, penggunaan hair product yang tidak cocok), faktor lingkungan (kelembapan lingkungan sekitar, polusi dan paparan sinar matahari berlebih), serta faktor psikologi yakni stres (Bergler-Czop dan Brzezińska-Wcisło, 2013; Devanthan, 2013).

Untuk mengatasi masalah ketombe, diperlukan suatu bahan yang aktif berkhasiat sebagai antiketombe. Bahan tersebut diantaranya dipyrithion, piroctone olamine, zinc pyrithione, selenium sulfida, asam salisilat, coal tar, hidrokortison, dan ketokonazol (Sweetman, 2009). Akan tetapi, bahan aktif yang banyak terkandung pada produk antiketombe adalah zinc pyrithione, selenium sulfida, asam salisilat, sulfur, coal tar, hidrokortison, dan ketokonazol baik dalam bentuk kombinasi maupun tunggal (Schwartz, DeAngelis dan Dawson, 2016). Selain itu, pengatasan masalah ketombe dapat juga dilakukan menggunakan bahan alami, seperti lidah buaya (Aloe vera), jeruk nipis (Citrus aurantifolia), daun teh (Camellia sinensis), biji srigading (Nyctanthes arbor-tristis), ekstrak rimpang jahe (Zingiber officinalis), daun sirih (Piper betle), bunga kembang sepatu (Hibiscus rosa-sinensis), daun pacar kuku (Lawsonia inermis), buah kecubung (Datura metel), dan kernel mangga (Mangifera indica) (Kothari, Patidar dan Solanki, 2018). Bahan alam yang banyak terkandung dalam produk antiketombe adalah minyak daun teh (Camellia sinensis), mimba (Azadirachta indica), rosemary (Rosmarinus officinalis), akasia (Acacia sinuata), malaka (Emblica officinalis), cendana (Santalum album), dan ruku-ruku (Ocimum tenuiflorum) (Kothari, Patidar dan Solanki, 2018). Pemakaian sampo dan obat antiketombe maupun bahan alam, keduanya dianjurkan karena terbukti dapat mengatasi masalah ketombe (Devanthan, 2013).

Selain menggunakan produk antiketombe maupun bahan alam, pengatasan masalah ketombe juga harus diikuti dengan perilaku hidup sehat. Perilaku hidup sehat yang dapat dilakukan adalah menjaga kebersihan diri, berjemur di bawah sinar matahari, memperbanyak konsumsi air putih, diet yang sehat dan bergizi, serta mengendalikan stres. Menjaga kebersihan diri merupakan cara paling murah untuk menjaga tubuh agar tetap sehat (WHO, 2009). Menurut American Academy of Dermatology (2010), melalui paparan sinar matahari pagi atau petang terhadap kulit kepala selama beberapa menit dapat membantu produksi vitamin D dan minyak yang dapat membantu mengurangi ketombe. Selain itu, dengan memperbanyak konsumsi air putih minimal 8 sampai 10 gelas per hari dapat membantu menghilangkan racun dan bahan lain yang berbahaya bagi tubuh (Weston, 2010). Menjaga diet yang sehat dan seimbang sangat penting dilakukan untuk penderita ketombe. Makanan yang dianjurkan adalah makanan yang kaya akan vitamin B karena dapat menstabilkan dan memberikan nutrisi ekstra pada kulit kepala. Selain itu, makanan seperti raw food, terutama yang masih segar, serta sayur dan buah-buahan sangat dianjurkan untuk menghindari kekeringan dan pengelupasan kulit kepala. Akan tetapi, Makanan berminyak, makanan dengan kandungan gula yang tinggi, lemak hewan, junk food, tepung, dan seafood sangat tidak dianjurkan untuk penderita ketombe (Timby dan Smith, 2011). Stres dapat menyebabkan berbagai masalah kesehatan termasuk ketombe sehingga pengendalian stres sangat diperlukan. Pengendalian stres dapat dilakukan dengan berolahraga, meditasi, dan tidur yang cukup yaitu tujuh hingga delapan jam setiap harinya (Nina, 2013).

Masyarakat perlu memahami pentingnya kesehatan kulit kepala dan pengatasan masalah ketombe. Akan tetapi, kepedulian masyarakat terhadap masalah dan penanganan ketombe masih cukup rendah. Hal ini dibuktikan dengan penelitian yang dilakukan oleh Harum et al. (2017), bahwa sebanyak 48\% responden tidak memiliki kesadaran akan pentingnya kesehatan kulit kepala dan bebas dari ketombe yang ditunjukkan dengan kurang aktifnya responden dalam mengakses informasi yang berkaitan dengan ketombe. Sementara itu, apabila masalah ketombe tidak mendapatkan perhatian, ketombe dapat menyebabkan masalah kulit lainnya, seperti jerawat baik pada kulit kepala, wajah maupun punggung, kulit kepala gatal, psoriasis, rambut rontok, dan rambut berminyak. Selain menimbulkan masalah kulit lainnya, adanya ketombe dapat menimbulkan masalah psikologis seperti ketidaknyamanan dan tidak percaya diri ketika berada di komunitas karena kulit kepala gatal yang sangat mengganggu, serta menimbulkan kesan tidak higienis pada seseorang yang mengalami ketombe (Achroni, 2012).

Rendahnya kepedulian dan upaya pencarian informasi terkait ketombe menyebabkan pengetahuan mengenai ketombe menjadi sangat terbatas, sehingga berdampak pada tindakan dalam mengatasi ketombe yang salah seperti penggunaan produk antiketombe yang 
kurang tepat. Oleh karena itu, peningkatan kesadaran terkait permasalahan ketombe perlu ditingkatkan agar dapat mencegah dan mengatasi masalah ketombe dengan tepat.

\section{METODE PENELITIAN}

Jenis penelitian ini adalah penelitian cross-sectional dan berupa penelitian deskriptif. Dilakukan perhitungan jumlah sampel dengan populasi tidak diketahui dan didapatkan minimal besar sampel sebanyak 98 responden. Perhitungan minimal besar sampel menggunakan rumus simple random sampling untuk populasi (n) tidak diketahui (Lemeshow et al., 1990).

$$
n=\frac{Z_{1-\frac{\alpha}{2}}^{2} P(1-P)}{d^{2}}
$$

Instrumen yang digunakan dalam penelitian ini berupa kuesioner semi-opened dan diisi sendiri oleh responden. Kuesioner terdiri dari 32 pertanyaan terkait pengetahuan dan penggunaan produk antiketombe. Sebelum digunakan, kuesioner telah divalidasi pada 10 individu diluar sampel.

Populasi responden adalah mahasiswa pria Universitas Pembangunan Nasional Veteran Surabaya dengan kriteria inklusi pernah mengalami masalah ketombe dan pernah menggunakan produk antiketombe. Teknik pengambilan sampel dilakukan dengan teknik accidental sampling. Pengambilan data dilakukan pada tanggal 27 - 30 September 2019.

\section{Analisa Data}

Analisa data dilakukan secara deskriptif menggunakan program IBM SPSS Statistic versi 25.0. Data karakteristik responden dan data praktik pemilihan dan penggunaan produk antiketombe disajikan dalam bentuk persentase (\%) dan frekuensi (n) yang ditampilkan dalam bentuk tabel. Sedangkan data pengetahuan terkait pemilihan dan penggunaan produk antiketombe diolah dengan menggunakan skor. Kategori dari skor pengetahuan adalah rendah dengan skor $0-3$, sedang dengan skor $4-6$, dan tinggi dengan skor $7-10$.

Tabel 1. Karakteristik Responden ( $\mathrm{n}=98)$.

\begin{tabular}{llc}
\hline \multicolumn{1}{c}{ Variabel } & Jawaban & $\mathrm{n}(\%)$ \\
\hline $\begin{array}{l}\text { Umur (Rata-rata, min, } \\
\text { maks) tahun }\end{array}$ & & $20,17,25$ \\
\hline Program Studi & Noneksakta & $50(51,0)$ \\
& Eksakta & $48(49,0)$ \\
\hline Pernah mengalami & Ya & $47(48,0)$ \\
ketombe & Tidak & $52(52,0)$ \\
\hline Pernah menggunakan & & \\
produk antiketombe & Ya & $55(56,1)$ \\
& Tidak & $43(43,9)$ \\
\hline \hline
\end{tabular}

\section{HASIL DAN PEMBAHASAN}

\section{Pengetahuan tentang Produk Antiketombe}

Sebanyak 48,0\% (47/98) responden dengan rentang usia 17 - 25 tahun pernah mengalami ketombe (Tabel 1).
Mahasiswa yang akan melakukan swamedikasi terkait keluhan ketombe harus memiliki pengetahuan tentang ketombe dan produk antiketombe, sehingga dapat menggunakan produk yang sesuai dengan keluhannya. Berdasarkan hasil penelitian ini, hanya sebanyak $26,53 \%$ responden yang memiliki pengetahuan yang tinggi mengenai produk antiketombe (Tabel 3).

Tabel 2. Distribusi Jawaban Mahasiswa terhadap Pengetahuan tentang Produk Antiketombe $(\mathrm{n}=98)$.

\begin{tabular}{lcc}
\hline \hline & \multicolumn{2}{c}{$\mathrm{n}(\%)$} \\
\cline { 2 - 3 } Pertanyaan & Tepat & $\begin{array}{c}\text { Tidak } \\
\text { tepat }\end{array}$ \\
\hline Kesesuaian indikasi produk & $46(46,9)$ & $52(53,1)$ \\
\hline Tujuan penggunaan produk & $68(69,4)$ & $30(30,6)$ \\
\hline $\begin{array}{l}\text { Macam-macam penyebab } \\
\text { ketombe }\end{array}$ & $33(33,7)$ & $65(66,3)$ \\
\hline $\begin{array}{l}\text { Batasan takaran penggunaan } \\
\text { produk }\end{array}$ & $84(85,7)$ & $14(14,3)$ \\
\hline Efek samping produk & $39(39,8)$ & $59(60,2)$ \\
\hline $\begin{array}{l}\text { Penanganan terhadap efek } \\
\text { samping }\end{array}$ & $56(57,1)$ & $42(42,9)$ \\
\hline Period after opening & $10(10,2)$ & $88(89,8)$ \\
\hline Pengertian nomor registrasi & $55(56,1)$ & $43(43,9)$ \\
\hline Contoh nomor registrasi & $55(56,1)$ & $43(43,9)$ \\
\hline
\end{tabular}

Pengetahuan mengenai sebuah produk merupakan syarat untuk melakukan swamedikasi (World Health Organization, 1998). Pengetahuan mengenai penyebab dari sakit yang dialami oleh seseorang diperlukan dalam menggunakan produk. Dari hasil penelitian ini, didapatkan bahwa pengetahuan mahasiswa mengenai macam-macam penyebab ketombe masih rendah, karena hanya $33,7 \%$ reponden menjawab dengan tepat (Tabel 2). Sebanyak $66,3 \%$ responden menjawab kutu sebagai penyebab dari ketombe (Tabel 2). Seharusnya penyebab utama ketombe adalah jamur (DeAngelis et al., 2007), minyak berlebih (Schwartz dan Dawson, 2017), dan salah satu penelitian mengungkapkan bahwa penggunaan pomade yang berlebih dapat menyebabkan ketombe (Utami et al., 2018).

Tabel 3. Distribusi Skor Pengetahuan Mahasiswa Terkait Produk Antiketombe $(\mathrm{n}=98)$.

\begin{tabular}{cc}
\hline \hline Kriteria & $\mathrm{n}(\%)$ \\
\hline Rendah & $16(16,3)$ \\
\hline Sedang & $56(57,2)$ \\
\hline Tinggi & $26(26,5)$ \\
\hline
\end{tabular}

Hasil identifikasi pengetahuan lain yang masih kurang adalah terkait adanya efek samping dari produk antiketombe yang digunakan, hanya $39,8 \%$ dari responden menjawab tepat (Tabel 2). Menurut penelitian Trüeb (2007), penggunaan sampo antiketombe dapat menyebabkan beberapa efek samping yaitu kerontokan rambut dan rasa sakit pada kulit kepala. Kerontokan rambut dilaporkan berasal dari efek keratolitik dari bahan aktif sampo antiketombe. Sedangkan untuk rasa sakit pada kulit, dilaporkan berasal dari sel-sel kutikula yang 
terangkat dari sel-sel kulit kepala yang rusak dapat saling bertautan dan sebagai hasilnya terjadi gesekan yang menimbulkan listrik statis dan membuat rambut menjadi kusut (Trüeb, 2007).

Sampo merupakan salah satu produk kosmetika di mana setelah produk dibuka, batas waktu penggunaan tidak lagi mengikuti tanggal kedaluwarsa yang tertera pada kemasan melainkan mengikuti batas waktu setelah dibuka atau period after opening (PAO) (Campanella dan Costanza, 2011). Dari hasil penelitian ini, pengetahuan responden mengenai period after opening dari produk antiketombe masih kurang (10\%) (Tabel 2). Sehingga bila seseorang menggunakan produk antiketombe, harus memperhatikan PAO dari produk tersebut. Efek bila menggunakan produk yang melebihi batas PAO adalah efektifitas bahan aktif yang menurun sehingga produk sudah tidak dapat berfungsi secara maksimal kembali (Campanella dan Costanza, 2011).

\section{Penggunaan Produk Antiketombe}

Dari 98 responden, 55 orang pernah menggunakan produk antiketombe. Dari data hasil penggunaan produk antiketombe oleh responden, produk dengan kandungan zink pirition yang paling banyak digunakan yaitu sebanyak 96,3\% dari 55 responden tersebut (Tabel 4). Menurut Schwartz, DeAngelis dan Dawson (2016), bahan aktif yang banyak terkandung pada produk antiketombe adalah zink pirition, selenium sulfida, asam salisilat, sulfur, coal tar, hidrokortison, dan ketokonazol baik dalam bentuk kombinasi maupun tunggal. Hal ini sesuai karena banyaknya penggunaan zink piriton pada produk antiketombe menjadikannya produk yang banyak digunakan.

Tabel 4. Kandungan Bahan Aktif pada Produk Antiketombe dan Pertimbangan Pemilihan Produk Antiketombe $(\mathrm{n}=55)$.

\begin{tabular}{ll}
\hline & $\mathrm{n}(\%)$ \\
\hline $\begin{array}{l}\text { Bahan aktif pada produk } \\
\text { antiketombe* }\end{array}$ & \\
Ketoconazole & $1(1,9)$ \\
Selenium sulfat & $2(3,7)$ \\
Tea tree oil & $1(1,9)$ \\
Zink pirition & $52(96,3)$ \\
Zink sulfat & $1(1,9)$ \\
\hline Pertimbangan pemilihan produk* & \\
Bentuk fisik produk & \\
Pengaruh iklan & $5(9,1)$ \\
Merek produk & $3(5,5)$ \\
Nomor registrasi & $16(29,1)$ \\
Saran orang lain & $2(3,6)$ \\
Indikasi & $4(7,3)$ \\
Kenyamanan & $15(27,3)$ \\
\hline \hline
\end{tabular}

\begin{tabular}{ll}
\hline Harga produk & $13(23,6)$ \\
Komposisi produk & $13(23,6)$ \\
Efek samping & $4(7,3)$ \\
Tanpa pertimbangan & $3(5,5)$ \\
Internet & $2(3,6)$ \\
& $1(1,8)$ \\
\hline \hline
\end{tabular}

Ket. $*$ = responden dapat memilih lebih dari satu jawaban.

World Health Organization (WHO) menyatakan pemilihan sediaan farmasetika dalam swamedikasi harus sesuai dengan indikasi sehingga sediaan dapat berkhasiat. Sedangkan hanya $27,3 \%(n=55)$ mahasiswa yang memilih produk antiketombe berdasarkan indikasi (Tabel 4). Sebanyak $29,1 \% \quad(n=55)$ mahasiswa mempertimbangkan merek dalam memilih produk antiketombe (Tabel 4). Hal ini sesuai dengan Kotler dan Armstrong (2011) yaitu keputusan konsumen dalam membeli suatu produk umumnya yaitu membeli merek yang paling disukai, tetapi ada faktor lain seperti saran atau rekomendasi orang lain serta adanya keadaan yang tidak terduga.

Hal penting yang harus diperhatikan dalam pemilihan produk antiketombe adalah informasi yang tertera pada kemasan produk (World Health Organization, 1998). Sebanyak lebih dari setengah responden yang menggunakan produk tersebut $(56,4 \%$; $\mathrm{n}=55$ ) tidak memperhatikan informasi yang tertera pada kemasan produk antiketombe (Tabel 5). Hal ini berarti kesadaran responden dalam memperhatikan informasi penting pada kemasan produk antiketombe masih rendah. Dari beberapa informasi yang tertera pada kemasan produk antiketombe, kegunaan $(56,5 \% ; n=55)$ dan komposisi $(52,5 \% ; n=55)$ merupakan informasi yang paling banyak dibaca oleh responden, serta sejumlah $4,3 \%(n=55)$ responden tidak mengecek nomor registrasi dari produk antiketombe (Tabel 5). Izin edar adalah izin untuk obat yang diproduksi untuk diedarkan di wilayah Indonesia berdasarkan penilaian terhadap keamanan, mutu, dan kemanfaatan (Badan Pengawasan Obat dan Makanan, 2016). Sehingga nomor izin edar atau nomor registrasi produk harus diperhatikan saat akan memilih produk swamedikasi untuk memastikan bahwa produk telah terdaftar di Badan POM agar terjamin keamanan, khasiat, dan mutunya.

Selain memperhatikan indikasi, pertimbangan terkait aspek keamanan produk antiketombe perlu diperhatikan. Namun berdasarkan hasil penelitian, sebanyak 94,5\% dari 55 responden ini tidak mempertimbangkan keamanan dalam memilih 
Tabel 5. Penggunaan Produk Antiketombe $(n=55)$.

\begin{tabular}{|c|c|c|c|}
\hline No. & Aspek Penggunaan & Jawaban & $\mathrm{n}(\%)$ \\
\hline \multirow[t]{15}{*}{1.} & Informasi & & \\
\hline & \multirow{2}{*}{$\begin{array}{l}\text { Responden membaca informasi pada kemasan sebelum } \\
\text { membeli }\end{array}$} & $\mathrm{Ya}$ & $23(41,8)$ \\
\hline & & Tidak & $31(56,4)$ \\
\hline & \multirow[t]{6}{*}{ Informasi yang dibaca pada kemasan* $(n=23)$} & Komposisi & $12(52,5)$ \\
\hline & & Cara pemakaian & $8(34,8)$ \\
\hline & & Kegunaan & $13(56,5)$ \\
\hline & & Efek samping & $1(4,3)$ \\
\hline & & Tanggal kedaluwarsa & $5(21,7)$ \\
\hline & & Nomor registrasi & $1(4,3)$ \\
\hline & \multirow{2}{*}{$\begin{array}{l}\text { Responden mencari informasi terkait risiko keamanan } \\
\text { atau alergi selain dari kemasan }\end{array}$} & $\mathrm{Ya}$ & $16(29,1)$ \\
\hline & & Tidak & $38(69,1)$ \\
\hline & \multirow{4}{*}{$\begin{array}{l}\text { Sumber informasi mengenai risiko keamanan atau } \\
\text { alergi* }(n=16)\end{array}$} & Internet & $11(68,8)$ \\
\hline & & Sosial media & $1(6,3)$ \\
\hline & & Dokter & $1(6,3)$ \\
\hline & & Kemasan & $2(12,5)$ \\
\hline \multirow[t]{9}{*}{2.} & \multicolumn{3}{|l|}{ Cara Penggunaan } \\
\hline & \multirow{2}{*}{$\begin{array}{l}\text { Responden menggunakan produk sesuai dengan } \\
\text { instruksi dokter/brosur produk/aturan pakai pada } \\
\text { kemasan }\end{array}$} & $\mathrm{Ya}$ & $35(63,6)$ \\
\hline & & Tidak & $20(36,4)$ \\
\hline & \multirow{2}{*}{$\begin{array}{l}\text { Responden meningkatkan jumlah takaran penggunaan } \\
\text { produk saat ketombe semakin parah }\end{array}$} & $\mathrm{Ya}$ & $11(20)$ \\
\hline & & Tidak & $44(80)$ \\
\hline & \multirow[t]{4}{*}{ Frekuensi penggunaan produk } & 2-3 kali seminggu & $23(41,8)$ \\
\hline & & Ketika merasa gatal & $12(21,8)$ \\
\hline & & Ketika ingat & $4(7,3)$ \\
\hline & & Setiap hari & $12(21,8)$ \\
\hline \multirow[t]{6}{*}{3.} & \multicolumn{3}{|l|}{ Alergi } \\
\hline & \multirow{2}{*}{$\begin{array}{l}\text { Responden yang pernah mengalami alergi akibat } \\
\text { penggunaan produk }\end{array}$} & $\mathrm{Ya}$ & $1(1,8)$ \\
\hline & & Tidak & $54(98,2)$ \\
\hline & Reaksi alergi yang dialami oleh responden $(n=1)$ & Ketombe berlebih & $1(100)$ \\
\hline & \multirow[t]{2}{*}{ Langkah yang dilakukan untuk mengatasi alergi* $(n=1)$} & Menggaruk ketombe & $1(100)$ \\
\hline & & Mengganti produk & $1(100)$ \\
\hline \multirow[t]{7}{*}{4.} & \multicolumn{3}{|l|}{ Penyimpanan } \\
\hline & \multirow{2}{*}{$\begin{array}{l}\text { Responden yang menyimpan produk yang tidak habis } \\
\text { digunakan }\end{array}$} & $\mathrm{Ya}$ & $11(20,0)$ \\
\hline & & Tidak & $44(80,0)$ \\
\hline & \multirow[t]{4}{*}{ Penyimpanan produk* $(\mathrm{n}=11)$} & 2 minggu & $1(9)$ \\
\hline & & $1-2$ bulan & $2(18,2)$ \\
\hline & & $3-4$ bulan & $2(18,2)$ \\
\hline & & Sampai tanggal kedaluwarsa & $5(45,5)$ \\
\hline
\end{tabular}

Ket. $*$ = responden dapat memilih lebih dari satu jawaban.

antiketombe (Tabel 4). Hal ini menggambarkan masih minimnya kewaspadaan mahasiswa terkait efek samping yang dapat terjadi dari penggunaan produk antiketombe. Sebanyak 17 dari 55 mahasiswa yang menggunakan produk antiketombe, mencari informasi tentang efek samping produk antiketombe (Tabel 5). Hanya satu mahasiswa yang membaca pada kemasan, sehingga 11 mahasiswa lainnya mencari informasi tentang efek samping produk antiketombe dari internet. Hal ini cukup berbahaya karena sebuah penelitian terdahulu melaporkan adanya kasus alergi dari penggunaan produk shampo antiketombe dengan bahan aktif zink pirition (ZPT) yang menyebabkan ruam pruritus di kulit kepala, wajah, leher dan tangan pada pria 33 tahun di Taiwan (Hsieh, Tu dan $\mathrm{Wu}, 2010$ ).
Untuk meningkatkan efektifitas dari penggunaan produk antiketombe, maka frekuensi penggunaan yang sesuai perlu diperhatikan. Berdasarkan hasil survei terhadap frekuensi penggunaan produk antiketombe, hasil terbanyak adalah dengan penggunaan $2-3$ kali seminggu $(41,8 \%)$ dan ketika merasa gatal $(21,8 \%)$. Sedangkan sebanyak $21,8 \%$ mahasiswa menggunakan produk antiketombe setiap hari dan $7,3 \%$ dari 51 mahasiswa yang menggunakan produk antiketombe ketika ingat (Tabel 5). Frekuensi penggunaan produk antiketombe berbeda-beda, bergantung dari jenis bahan aktif yang terdapat dalam produk antiketombe. Produk antiketombe berupa sampo dengan bahan aktif zink pirition digunakan $2-3$ kali seminggu, sampo dengan bahan aktif selenium sulfat digunakan 2 kali seminggu pada minggu pertama, kemudian 1 kali seminggu pada minggu berikutnya, dan sampo dengan bahan aktif ketokonazol digunakan 2 kali seminggu selama $2-4$ minggu (Nathan, 2010). 
Berdasarkan data penelitian didapatkan bahwa hanya $1,8 \%(\mathrm{n}=55)$ mahasiswa pernah mengalami reaksi alergi akibat penggunaan produk antiketombe. Mahasiswa tersebut melaporkan bahwa produk antiketombe yang digunakan adalah sampo dengan bahan aktif zink pirition (ZPT). Sisanya, sebanyak 98,2\% $(n=55)$ mahasiswa tidak pernah mengalami reaksi alergi apapun. Hsieh, Tu dan Wu (2010) melaporkan bahwa terdapat kasus alergi yang disebabkan oleh zink pirition yang terkandung dalam sampo antiketombe. Sebagian besar kasus disertai dengan dermatitis pada kulit kepala dan seringkali meluas hingga ke wajah, leher, bahu, dan tangan. Kasus alergi yang dilaporkan oleh responden, yaitu mengalami reaksi ketombe yang justru berlebih (Hsieh, Tu dan Wu, 2010). Sementara itu, praktik penanganan reaksi alergi yang dilakukan oleh mahasiswa adalah menggaruk kulit kepala dan mengganti produk antiketombe (Tabel 5).

Sebanyak 20,0\% (n=55) mahasiswa menyimpan sisa produk antiketombe yang tidak habis dan mahasiswa menyimpan produk tersebut hingga tanggal kedaluwarsa terlewati $(45,5 \%$; $\mathrm{n}=11)$ (Tabel 5). Produk antiketombe memiliki waktu period after opening yang menunjukkan periode waktu dimana setelah pembukaan produk dapat digunakan tanpa efek berbahaya (Campanella dan Costanza, 2011).

\section{KESIMPULAN}

Pengetahuan mahasiswa mengenai macam-macam penyebab ketombe, efek samping produk antiketombe, dan period after opening produk antiketombe masih kurang dan hanya sebagian dari mahasiswa yang memperhatikan informasi yang tertera pada kemasan. Kewaspadaan mahasiswa terkait efek samping produk antiketombe juga masih rendah.

\section{UCAPAN TERIMA KASIH}

Terimakasih kepada Ibu Anila Impian Sukorini, S.Si., M.Farm., Apt atas bimbingannya dalam menyusun manuskrip dan penelitian ini.

\section{DAFTAR PUSTAKA}

Achroni, K. 2012. Semua Rahasia Kulit Cantik dan Sehat Ada Disini. Jogjakarta: PT. Buku Kita.

American Academy of Dermatology. 2010. Seborrheic Dermatitis. Diakses dari http://www.aad.org/public/publication/pamphlets/c ommon_seb_dermatitis.html, pada tanggal 4 November 2019.

Badan Pengawasan Obat dan Makanan. 2016. Peraturan Kepala Badan Pengawas Obat dan Makanan Republik Indonesia No. 26 Tahun 2016 Tentang Pelayanan Perizinan Berusaha Terintegrasi Secara Elektronik Sektor Obat dan Makanan. Jakarta.

Bergler-Czop, B. dan Brzezińska-Wcisło, L. 2013. Dermatological Problems of the Puberty. Postepy Dermatol Alergol. Vol. 30. No. 3, pp. 178-187.
Campanella, L. dan Costanza, C. 2011. Period After Opening. J. Appl . Cosmetol. Vol. 29. p. 44.

DeAngelis, Y. M., Saunders, C.W., Johnstone, K. R., Reeder, N. L., Coleman, C. G., Kaczvinsky Jr, J. R., Gale, C., Walter, R., Mekel, M., Lacey, M. P., Keough, T. W., Fieno, A., Grant, R. A., Begley, B., Sun, Y., Fuentes, G., Youngquist, R. S., Xu, J., dan Dawson Jr., T. L. 2007. Isolation and Expression of a Malassezia globosa Lipase Gene, LIP1. Journal of Investigative Dermatology. Vol. 127. No. 9. pp. 2138-2146

Devanthan, V. 2013. Feature Article: The Dandruff Menace. Science Report. pp. 24-27.

Harum, N. F., Djayanti, K., Widyanti, S., Nurjanah, Y. A., Masruroh, F., Syamsuar, M., Nurlitasari, A., Faaza, T. A., Sari, R. D. K., Maulana, Y., Rahmawati, A., dan Sukarno, R. H. A. 2017. Profil Pengetahuan Mahasiswa dalam Mencegah dan Mengatasi Gangguan Ketombe. Jurnal Farmasi Komunitas. Vol. 4. No. 1. pp. 6-10.

Hsieh, C. W., Tu, M. E. dan Wu, Y. H. 2010. Allergic Contact Dermatitis Induced by Zinc Pyrithione in Shampoo: A Case Report. Dermatologica Sinica. Vol. 28. No. 4. pp. 163-166

Kothari, S., Patidar, K. dan Solanki, R. 2018. Polyherbal Anti-dandruff Shampoo : Basic Concept, Benefits, and Challenges. Asian Journal of Pharmaceutics. Vol. 12. No. 3. pp. 849-858.

Kotler, P. dan Armstrong, G. 2011. Principles of Marketing. 14th Ed. America: Pearson Education Inc.

Lemeshow, S., Hosmer Jr, D. W., Klar, J., dan Lwanga, S.K. 1990. Adequacy of Sample Size in Health Studies, World Health Organization. Chichester: John Wiley \& Sons Ltd.

Manuel, F. dan Ranganathan, S. 2011. A New Postulate on Two Stages of Dandruff: A Clinical Perspective. International Journal of Trichology, Vol. 3, No. 1, pp. 3-6.

Misery, L., Rahhali, N., Duhamel, A., dan Taieb, C. 2013. Epidemiology of Dandruff, Scalp Pruritus and Associated Symptoms. Acta DermatoVenereologica. Vol. 93. No. 1. pp. 80-81.

Nathan, A. 2010. Non-prescription Medicines. $4^{\text {th }}$ Ed. London: Pharmaceutical Press.

Nina, M. 2013. 14 Simple Steps to Deal with Dandruff. Diakses dari http://www.uptodate.com, pada tanggal 4 November 2019.

Ranganathan, S. dan Mukhopadhyay, T. 2010. Dandruff: The Most Commercially Exploited Skin Disease. Indian J Dermatol. Vol. 55. No. 130. pp. 130-134.

Schwartz, J.R, Deangelis, Y.M, dan Dawson, T.L. 2016. Dandruff and Seborrheic Dermatitis: A Head Scratcher. JLA. Vol. 11. No. 12. pp. 1-26

Schwartz, J. R. dan Dawson, T. L. 2017. Dandruff and Seborrheic Dermatitis. in Baran, R. dan Maibach, H. I. (eds). Textbook of Cosmetic Dermatology. 5th Edition. Boca Raton: CRC Press. pp. 246-258.

Sweetman, S. C. 2009. Martindale: The Complete Drug Reference. 36th Ed. London: Pharmaceutical Press. 
Timby, B. K. dan Smith, N. E. 2011. Introductory Medical Surgical Nursing. 9th Ed. London: Lippincott Williams \& Wilkins.

Trüeb, R. M. 2007. Shampoos: Inhaltsstoffe, Wirkungen und Nebenwirkungen. Journal of the German Society of Dermatology. Vol. 5. No. 5. pp. 356366.

Utami, A. R., Sukohar, A., Setiawan, G., dan Morfi, C. W. 2018. Pengaruh Penggunaan Pomade Terhadap Kejadian Ketombe Pada Remaja Pria. MAJORITY. Vol. 7. No. 2. pp. 187-192.
Weston, W. L. 2010. Overview of Dermatitis. Diakses dari http://www.uptodate.com, pada tanggal 4 November 2019.

World Health Organization. 2009. WHO Country Report Allergic Rhinitis. Diakses dari www.cureresearch.com/allergicrhinitis/statscountry.htm, pada tanggal 4 November 2019.

World Health Organization. 1998. The Role of the Pharmacist in Self-Care and Self-Medication. Diakses dari http://apps.who.int/medicinedocs/en/d/Jwhozip32e/ 3.html, pada tanggal 4 November 2019. 